\title{
Andrés Maldonado López
}

\author{
BELEN ALONSO ${ }^{1}$ and JOSÉ IGNACIO DÍAZ ${ }^{2}$ \\ ${ }^{1}$ Institut de Ciències del Mar, CSIC, Pg. Marítim de la Barceloneta 37-49, 08003 Barcelona, Catalunya, Spain. \\ E-mail: belen@icm.csic.es \\ ${ }^{2}$ Instituto Español de Oceanografía, CO Santander, Promontorio de San Martín s/n, 39010 Santander, Spain. \\ E-mail: jose.diaz@st.ieo.es
}

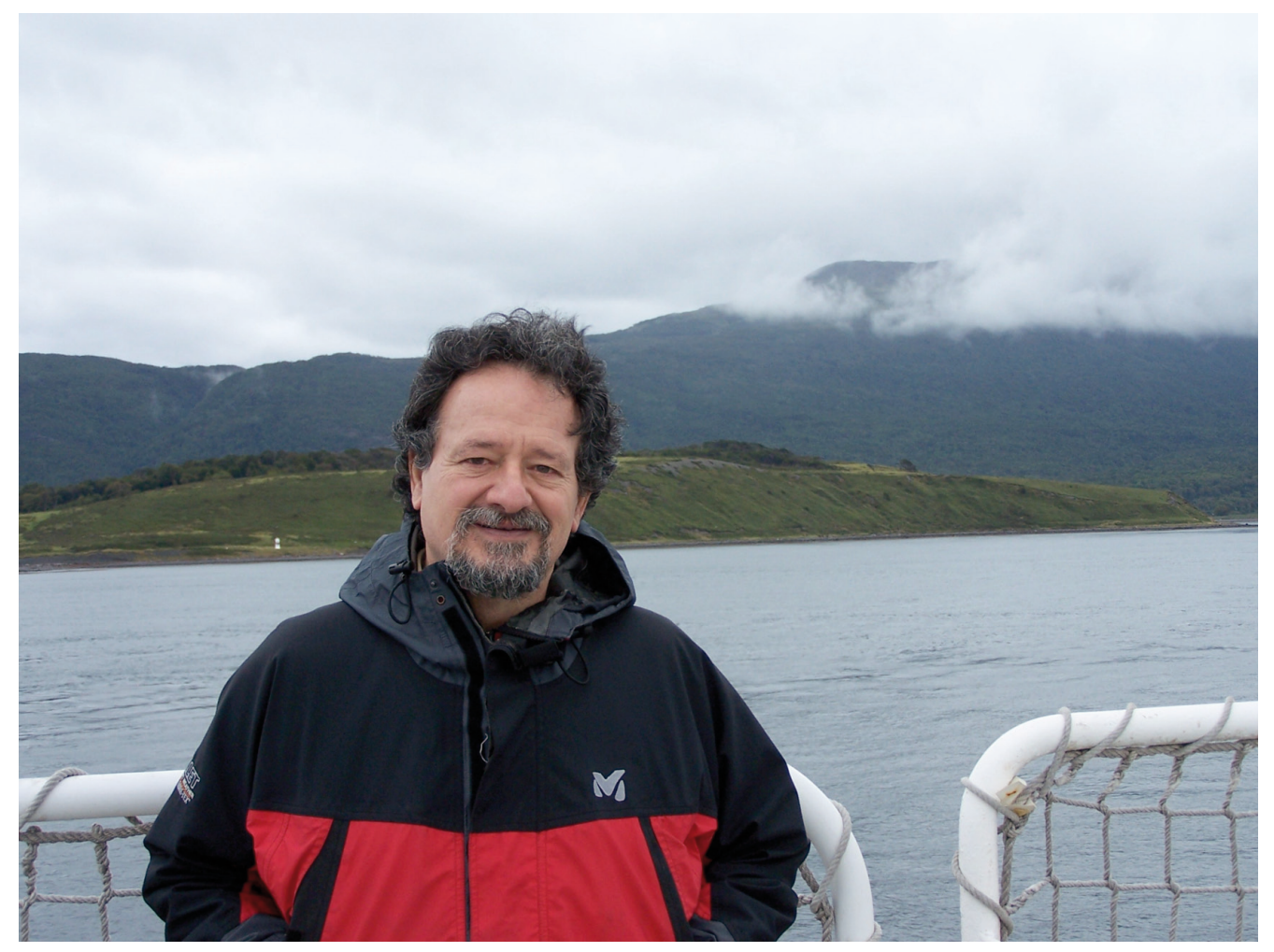

Andrés Maldonado López was born on 26 December 1944. He studied geology at the University of Granada, receiving his MSc. in 1968. That same year he became Assistant Professor of Geology at the University of Zaragoza working closely with Prof. Oriol Riba. One year later, in 1969, Maldonado moved with Riba to the Department of Stratigraphy and Historical Geology at the University of Barcelona. In 1972, he received his $\mathrm{Ph}$. D. from the University of Barcelona for a thesis on the Ebro Delta. In 1974 he became a permanent staff scientist of the Spanish Research Council (Consejo Superior de Investigaciones Científicas, CSIC), working at the Institut Jaume Almera (IJA) in Barcelona, but continued to teach at the University of Barcelona in various associate professor positions. Maldonado and Riba were among the pioneers in marine geology studies in Spain.

In 1979, Maldonado was responsible for the establishment of a marine geology unit within the IJA. This unit was initially housed on the second floor of the De- 
partment of Stratigraphy and Historical Geology of the University of Barcelona in Plaça Universitat. In 1980 it moved to the CSIC administration building in Barcelona on Egipcíaques St., and then later on, in 1982, the IJA moved to new facilities in the university area of Barcelona. In 1984, at the age of 40, Maldonado became a research professor of CSIC. In 1987 he moved with his already established and consolidated marine geology research group to the Institute of Fisheries Research (Instituto de Investigaciones Pesqueras, IIP) of CSIC, also in Barcelona, which then changed to its current name of Institute of Marine Sciences (Institut de Ciències del Mar, ICM), in part to include marine geology as a new discipline. From 1988 to $1991 \mathrm{Mal}-$ donado split his management time between his directorship at the ICM and heading the Department of International Relationships of the CSIC in Madrid. In 1992, Maldonado requested to be assigned to the Andalusian Institute of Mediterranean Geology in his hometown of Granada. This institute, a joint CSIC and University of Granada centre later renamed the Andalusian Institute of Earth Sciences (Instituto Andaluz de Ciencias de la Tierra, IACT), is still his current workplace. He has been the director of the IACT twice (from 1998 to 2002 and from 2002 to 2006).

During the 1980s, Maldonado in collaboration with José Medialdea, the head of the marine geology area at the Spanish Geological and Mining Institute (Instituto Geológico y Minero de España, IGME), carried out systematic geological mapping studies of the Spanish continental shelves. These studies, which are still incomplete, were conducted as part of the FOMAR Programme for geological mapping of the Spanish continental margins at a scale of 1:200.000, funded by IGME. This situation, together with the significant funding from Spanish-American joint committee projects (1980-1988), was the catalyst for the recruitment and training of young graduates in geology in the marine geology unit at the IJA in Barcelona. In 1980 these graduates included Miquel Canals, Belén Alonso, Antonio Vázquez, José Ignacio Díaz and Marcel-lí Farran, and in 1981, Salvador Giró and Albert Palanques. A few years later, thanks to other research projects, other graduates became part of the unit, including Carlota Escutia, Jesús Baraza, Jorge Guillén and Gemma Ercilla, most of whom did their dissertations and doctoral theses under the direction of Maldonado. The research subjects covered coastal dynamics, geochemical processes and sediment dynamics, stratigraphy and sedimentology of continental margins, as well as submarine geotechnics, a discipline that was new and unique within CSIC at that time.

From 1979 to 1991, Maldonado's scientific career was devoted to increasing the knowledge of various scientific issues within the discipline of marine geology. Initially his research focused primarily on the western Mediterranean Sea, centring on the geophysical characterisation of lithoseismic units, the identification and characterisation of depositional media, and the mod-

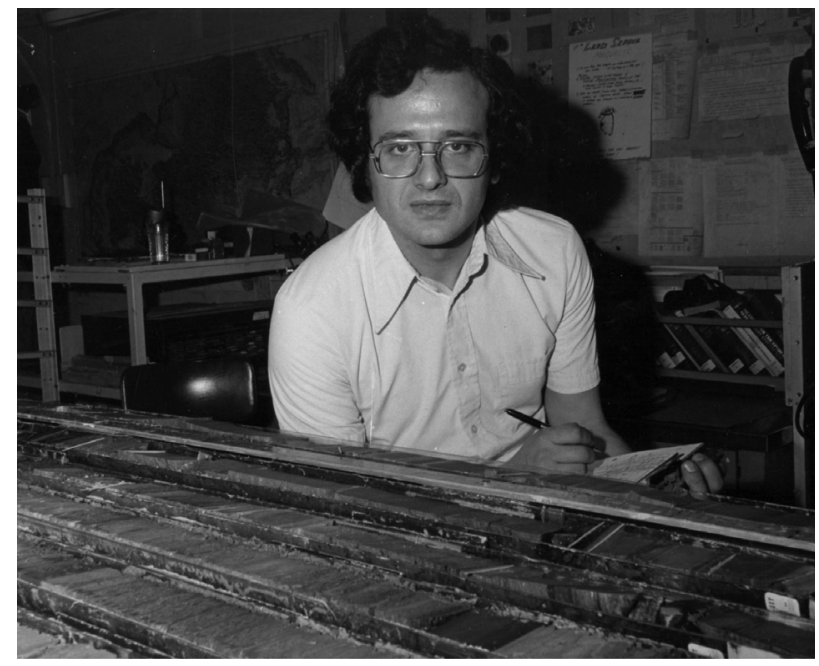

Characterising sediment cores during Leg 47 of the Ocean Drilling Programme, Western Atlantic (1976).

elling of the continental margin and deep basins. He also carried out geological analyses, and studies of risk assessment, evolution and continental shelf control parameters oriented at geological mapping and assessing non-renewable resources in the Iberian Peninsula. His research topics included the morphodynamic evolution of beaches with a large social impact, coastal evolution in relation to physical, morphological and sedimentological parameters, morphodynamics, work on pollution and advice to industry. In 1992, Maldonado redirected his research on the geophysical, geodynamic and structural aspects of marine geology, changing both subject matter and geographic study area. His interests have since focused primarily on the marine geology and geophysics of the continental margins and ocean basins of the Antarctic Peninsula, including the margins of the Pacific Ocean and the Scotia and Weddell Seas. He has studied the geodynamic evolution at plate boundaries, continental fragmentation processes and ocean basin development models. He has also analysed in depth the triple junction zones between plates, and active and passive continental margins related to the Antarctic, Scotia and Phoenix plates, as well as various geodynamic processes. His current focus is on palaeoceanographic changes and global change.

From the beginning of his research career Maldonado always understood the importance of international connections, which at the time were rare and difficult to obtain. In 1974 he went to the Smithsonian Institution in Washington (USA) as a scholar on the cultural exchange programme between Spain and the USA. Later he returned to the centre as a research associate for different periods in 1977 and from 2005 to 2007, working closely with renowned geologist Daniel Stanley. In 1993 he was a research associate at the Laboratory of Geodynamics, Tectonics and Environment of the University Pierre et Marie Curie in Paris, working with Alain Mauffret among others, and between 1995 and 1996 he was a research associate at the US Geo- 


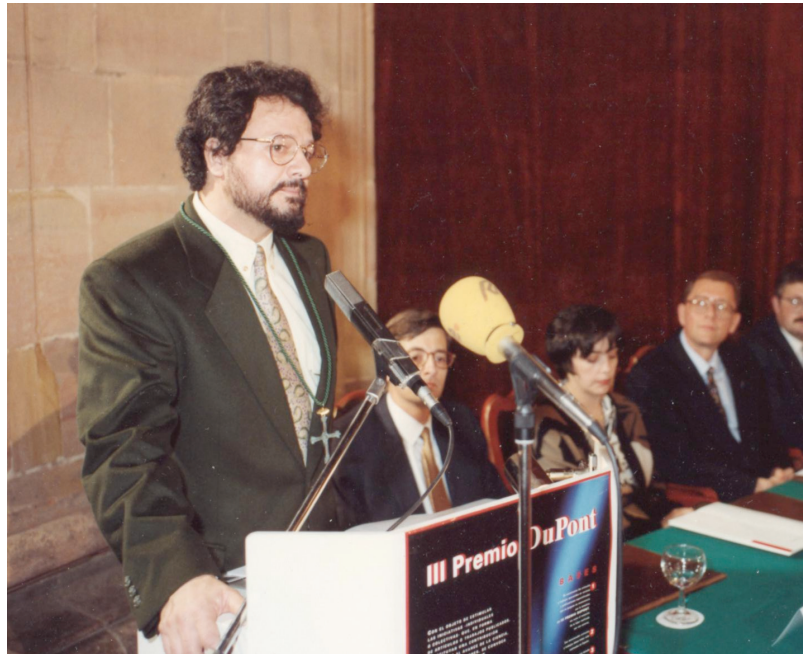

Award cerimony of the III DuPont prize for Science. Principality of Asturias, Spain (1992).

logical Survey, Menlo Park. It was at the USGS where he established a strong professional and personal relationship with Hans Nelson that has lasted to the present day. He also established a close relationship with Prof. Bill Ryan. He went on a research cruise with Ryan on the $R / V$ Robert $D$. Conrad in 1984 in the western Mediterranean (Ebro and Rhone submarine fans) and used for the first time in Spain a multi-beam echosounder and deep water side scan sonar (SeaMARC I) to obtain unprecedented images of the seabed. The cruise also provided the opportunity for young Spanish scientists to participate. Other relevant collaborations were with the CNRS, the University of Perpignan and the University Pierre et Marie Curie (France), the Experimental Geophysical Observatory in Trieste (Italy), the British Antarctic Survey, PETROBRAS and the University of Niteroi in Sao-Paulo (Brazil), and VNII Okeangeologiya in St. Petersburg (Russia). All of these collaborations gave him experience in various aspects of marine geology and helped to internationalise the marine geological science carried out in Spain.

One aspect that Maldonado always particularly focused on was the adaptation of ships and boats for marine geology and geophysics work. The oceanographic vessel Cornide de Saavedra was adapted and equipped in the early 1980s. Subsequently, this concern resulted in the modernisation of the oceanographic vessel García del Cid and, particularly, the design, construction and equipping of the BIO Hespérides.

Maldonado has been on more than 37 research cruises, and has been Chief Scientist on seven Antarctic campaigns. He still actively participates in national and international cruises. He has also participated in two Ocean Drilling Programme cruises (westerncentral Atlantic Ocean and the continental margin of the Antarctic Peninsula). He has an Antarctic cruise coming up in 2013. He has led eight research projects in the Antarctic. He has also been responsible for 13 other national and international research projects in the western Mediterranean, Atlantic Ocean and Gulf of Cadiz. He has supervised eight master dissertations and 10 doctoral theses. Maldonado has authored over 230 scientific publications. Of these, 90 are original articles published in journals included in the lists of the Institute for Scientific Information (ISI), another 17 articles have been published in ISI special volumes, and he has been editor or co-editor of a total of 31 national and international monographs. The remaining articles have been published in national and international journals. With an H-index factor of 24, several of his publications have received more than 100 citations.

Maldonado has also dedicated an important part of his time to teaching marine geology as a graduate professor at the Technical University of Catalonia (Universitat Politècnica de Catalunya, UPC), where he was co-director of the doctoral programme in marine sciences for five years (1986-1991) and associate professor in the School of Civil Engineering (1988-1992). Later, from 2000 to 2006 at the University of Granada, he taught the doctoral course "Coastal littoral flooding", including fluvial and coastal morphodynamic processes.

Andrés Maldonado is widely recognised among the main cross-disciplinary academic national and international institutions. He has received many awards, among them the "Alfonso X El Sabio" cross from the Ministry of Science and Education in 1971, and the DUPONT prize for science in 1992. Currently, Maldonado is founding member elect of the European Academy of Science, London (1987-present), corresponding member elect of the Royal Academy of Sciences and Arts of Barcelona (2000-present), and permanent member of the Academy of Mathematical, Physico-Chemical and Natural Sciences (Natural Sciences section) of Granada (2007-present).

\section{DIRECTORSHIP (1987-1991)}

Andrés Maldonado was nominated director of the IIP-ICM in 1987. At that time, CSIC was undergoing a broad restructuring of its research centres and there had even been talk about shutting down the IIP. CSIC organised a meeting with relevant IIP researchers in order to get to know the situation and their concerns, and encourage them to reach agreements for a new management. It was finally decided to opt for an even more ambitious marine sciences laboratory, including marine geology, changing the name to the Institute of Marine Sciences, and appointing Andrés Maldonado, then research professor at the Institut Jaume Almera (IJA) and head of the Marine Geology Research Unit, as the director of the ICM. This change brought with it a major refurbishment of the ICM facilities: the historic Barcelona aquarium was closed, and laboratory and office space was significantly increased. Among the areas that were restructured and enhanced was the computing service, considered an essential tool for all oceanography disciplines. 
Among Maldonado's main activities as director was the promotion and improvement of marine sciences in all of its disciplines at the ICM. This interest is evidenced by various measures aimed at improving the scientific and technical infrastructure, recruiting and training young researchers and obtaining greater visibility and internationalisation of the marine sciences.

The new project for the ICM included updating the B/O García del Cid research vessel by enhancing the multipurpose capabilities. A stern A-frame gantry was installed while the conventional fishing trawl-winch was replaced with a winch for a multipurpose deepwater cable, which, 25 years later, continues to be fully operational. In 1988, CSIC gave Maldonado the technical responsibility of advising the Bazán shipyard and the Spanish Navy in the construction of what would be an oceanographic research vessel with polar capabilities, the BIO Hesperides. He coordinated a multidisciplinary group of advisors from the various ICM departments: Jordi Salat, Jaume Rucabado, Miquel Alcaraz and José Ignacio Díaz. The contribution of the $B I O$ Hesperides to oceanic studies is one of the fundamental keys to understanding the progress of marine research in Spain in recent years. At the ICM, the scanning electron microscopy service was modernised and expanded with the addition of an X-ray microanalysis probe for qualitative and quantitative analysis of marine samples.

Maldonado has also promoted the teaching activities of ICM researchers in the post-graduate courses coordinated by Agustín Sánchez-Arcilla of the UPC School of Civil Engineering, and encouraged the in- corporation of marine geologists in order to promote greater multidisciplinarity and balance between marine disciplines. The composition of the Spanish marine research community was previously clearly predominated by biologists (Ministerio de Educación y Cultura, 1999), and Maldonado has contributed greatly to rectifying this imbalance.

It was during Maldonado's directorship at the ICM that the internationalisation of Spanish marine science research increased once again. A crucial milestone was when Spain joined the European Economic Community in 1986, when many ICM researchers became involved in the Framework Programme for R\&D with other European institutions. Of particular benefit was the implementation of the European Marine Science and Technology (MAST) programme. Maldonado also encouraged the temporary incorporation of prestigious foreign researchers for sabbatical stays. Finally, while he was the head of the CSIC Department of International Relationships, he contributed to establishing bilateral programmes, such as the one with Chile CONICET-CSIC, and made it possible for numerous international meetings to be held at the ICM.

\section{BIBLIOGRAPHY}

Conversations with Enrique Tortosa Martorell, summer 2012.

Conversations with Andrés Maldonado López, summer 2012.

Conversations with Joaquin Villena Morales, summer 2012.

Ministerio de Educación y Cultura. 1999. La Investigación en Ciencias Marinas en España. Dirección General de Enseñanza Superior e Investigación Científica, 86 pp.

Biography series ed.: F. Peters. 